\title{
The history of Japanese psychiatry and the rights of mental patients*
}

\author{
Etsuro Totsuka, Attorney-at-law (Japan) and Academic Visitor, Forensic Psychiatry, \\ Institute of Psychiatry, University of London
}

\section{Traditional attitudes towards mental illness in Japan}

In ancient Japan, written characters and religions were largely based on Chinese cultures. The first foreign physician was invited from Korea to Japan during the Shiragi Dynasty, when an Emperor became ill at the beginning of the 5th century. Since then, Chinese medicine dominated in Japan until Western medicine was introduced in the middle of the 19 th century.

For nearly a thousand years, the Japanese have read the story of Genji-Monogatari written by Shikibu Murasaki in Japanese characters. In it, one can find several passages which seem to describe mental illness. The ancient Japanese thought that this state of mind was caused by 'Mononoke' (a monster) or 'Kitsune' (a fox). These were able to enter into and take over the body of human beings. 'Mononoke' could be someone else's soul bringing a curse of fury, jealousy or hatred upon the mentally ill person. In order to cure this, the ancient Japanese asked priests to say special prayers. When the 'monster' or 'Kitsune' escaped from the body of the mentally ill person, the patient could then recover completely, so prognosis and recovery were probably better in those days than today.

Another important piece of literature that illustrates the Japanese attitude is a contemporary novel Narayamabushi-ko written by Shichiro Fukazawa (1964), which is based on an ancient legend. The legend tells of a folk tradition whereby old people were abandoned in the mountains and left to die.

In the middle of the 16th century, the Portuguese brought guns to Japan. The Japanese sword industry quickly learned how to produce guns. This radically changed the state of civil wars. Those who used guns most effectively took power. Western medicine, printing technology and the Roman Catholic Church were also introduced to Japan by the Portuguese. Missionaries built Western-style hospitals. They helped and cured the poor and severely ill, including the mentally ill. The influence of Western medicine soon declined, because Christian missionaries were

*Based on a lecture given at the Institute of Psychiatry, London, on 14 September 1989. persecuted and banned by the Tokugawa-GrandShogunate in the 17th century. The Shogunate was worried that Christianity and Western military power would undermine the newly set up Tokugawa Regime and therefore cut off Japan from the outside world for more than 200 years. No foreigner was allowed to enter the country. Any Japanese who secretly tried to go abroad was executed. Trading and the purchase of Western books were also banned. A rare exception was Dutch traders who were allowed to live in Dejima, a very tiny artificial island in Nagasaki.

During the Tokugawa era, Japanese families were allowed to confine their own mentally ill relatives in private cells at home. If a mentally ill relative committed a serious crime such as homicide, then families were ordered to confine him or her in a home cell.

\section{Modern psychiatry in the pre-war period}

Following the threatening journey of the Black Ships sent from the USA to Japan to force Japan into signing an unfair trade treaty, the Tokugawa Regime was brought down and, in 1868, the Meiji Restoration took over. The new Meiji Emperor's regime tried to reform Japan, introducing Western culture, technology, and legal and medical practices in order to catch up with the more powerful countries in the West. New national policies were drawn up to build greater wealth and create a strong military power in Japan. Western approaches to science, technology and industry were encouraged but without losing the traditional Japanese spirit. The Meiji Government tried not only to invite European and American scholars to Japan but also to send many of Japan's leading figures to foreign countries to learn as much as possible.

After some debate, in 1869, the new Government decided to introduce German medicine rather than British. Although a textbook written by Dr Henry Maudsley was published in Japanese in 1876, British psychiatry has had little influence on Japan (Kaneko, 1973). In 1886, Dr Hajime Sakaki was appointed as the first Japanese professor of psychiatry and opened the Department of Psychiatry at Tokyo University 
after four year's study in Germany. He was also appointed consultant psychiatrist at the Tokyo Metropolitan Lunatic Asylum.

It should be noted that, in introducing Western law, the Japanese had enormous difficulties; for example Japanese traditional legal concepts did not include some of the most basic precepts of Western legal philosophy such as 'human rights', 'freedom' or even any 'rights' at all. Under the strong influence of German law, the Great Japanese Imperial Constitution was proclaimed and Western style court procedures were introduced for criminal cases in 1890 . However, the rights of mental patients remained unprotected. In 1900, a law called 'Seishin-byosha Kango Ho' (The Confinement and Protection of the Mentally Ill Act) was passed and the traditional confinement of the mentally ill in cells at home was upheld.

It was estimated that there were some 65,000 mentally disordered persons in Japan in 1917 (Kaneko, 1973). Among them, about 4,500 were being confined in domestic cells in addition to some 5,000 in-patients in a small number of private and public lunatic asylums. The second professor of psychiatry at Tokyo University, Dr Shuzo Kure, who also studied in Germany, became extremely critical of the inhumane situation surrounding domestic cells. He lobbied ministers and senior officials and delivered his now famous report on this issue to MPs in 1918 (Kaneko, 1973). He and his followers requested the Japanese Government (the Taisho Dynasty) to create a comprehensive system of public mental hospitals so as to commit the domestic cells detainees into a more humane environment. As a result, in 1919 'Seishin-byoin Ho' (The Mental Hospital Act) was passed. The Government was given power to order local governments to build mental hospitals. The detention in mental hospitals of mental patients who were regarded as dangerous or difficult to treat, under the order of the authorities, and the confinement in home cells of non-dangerous mental patients, under the request of families, were encouraged. Despite this new law, public mental hospitals did not develop quickly and domestic confinement was still allowed.

During these years, the Japanese attitude towards the mentally ill was as follows. Mental illness was regarded as genetic, incurable, impossible to understand and dangerous, namely one of the worst diseases. As a result, the mentally ill were thought to be a disgrace to the family. The Japanese did not want to talk about them, did not want to see them, to hear about them, to get married to them, and did not want to employ them. Japanese families hid these mentally ill relatives in a cell at home or in a mental hospital. Even conscientious doctors and families thought mental patients would be happier in remote asylums rather than in the community. Thus, concern about public safety took precedence over patients' rights. This historic attitude towards the mentally ill has had its effect on subsequent and current approaches to psychiatry in Japan.

\section{The totalitarian era}

Japan colonised Manchuria in 1932 and invaded China in 1937. In that year, the number of deaths in mental hospitals rose suddenly and peaked in 1945 when Japan was defeated by the allied forces. Dr Naoki Tsukazaki points out that 2,000 in-patients died between 1941 and 1945 in the Metropolitan Matsuzawa Mental Hospital which had about 1,000 beds. He estimates that about 30,000 in-patients died during these four years in Japan's mental hospitals, mainly because they were not given proper food under detention. Thus the number of mental hospital beds decreased from 23,958 (in 1941) to 3,995 (in 1945) for the same period. The Japanese army and a team of its medical professionals led by $\mathrm{Dr}$ and General Ishii committed serious crimes against humanity in human experiments during these years. The so-called '731' special institutions caused the death of thousands of Chinese detainees in order to develop biological weapons. It is believed that, after World War II, the US Army gave those involved amnesty in exchange for massive confidential medical data on human experiments.

\section{Post-war Japan}

After the war many professionals were removed from public office by the General Head Quarters of occupying forces. These professionals were mainly military officers, politicians, senior officials and businessmen. However, very few leaders of the medical and legal professions were purged.

Under the advice of the Supreme Commander for the Allied Powers, General Douglas MacArthur, the Japanese Constitution, which was eventually supported by the majority of the Japanese public, was proclaimed by the National Diet (Parliament) in 1946. This completely changed Japanese law and policy. The new principles included: sovereign power of the people, peace, fundamental human rights and internationalism. In 1950, a law 'Seishin-Eisei Ho' (The Mental Hygiene Act) was passed and domestic confinement was prohibited for the first time in Japanese history.

But the human rights of mental patients were still forgotten and the principles and philosophy surrounding their detention remained unchanged.

The occupation ended in 1952 and Japan became independent.

In 1958, 'Kokumin-Kenko-Hoken Ho' (The National Health Insurance Act) was passed and the 
legal basis for 'health insurance for all' was achieved. Every Japanese could be covered by some form of health insurance. Both private practitioners and public medical institutions were paid for their medical services under the point system. This kind of socialisation made private practitioners fear for their deterioration. Their anticipation was completely wrong. Private practitioners and medical corporations became more prosperous because of this system. The private sector covered more than $80 \%$ of Japanese medical services and became a big industry. The problem then arose that medical practitioners were tending to become 'accountants' rather than health professionals.

\section{Current problems}

In 1981, I visited Professor John Gunn at the Institute of Psychiatry, Dr James MacKeith at the Interim Secure Unit at the Bethlem Royal Hospital and Dr J. Hamilton at Broadmoor Hospital in order to seek information about the legal system and the treatment of the mentally ill offenders in the UK.

The reasons for visiting were as follows. At that time in Japan, those who committed a crime because of insanity were not found guilty by the courts. The courts had no powers to order the detention of these patients. They were detained by a Governor of Prefecture indefinitely in a mental hospital under the Mental Hygiene Act article 29, provided that more than two psychiatrists agreed. But every time newspapers published sensational articles about incidents caused by mentally ill offenders, the Ministry of Justice tried to amend the Criminal Code in order to allow the courts to order a security measure detention for these patients in a maximum security institution under the control of the ministry. The Japan Federation of Bar Associations had always been opposed to this demand, as it was thought that detention under the Mental Hygiene Act was sufficient and that lawyers should not be involved in what was considered to be the business of psychiatrists. This was the only major issue surrounding the law and mental health in Japan at that time. The Ministry of Justice cited examples in Europe of the successful involvement of the criminal courts in the detention of mental patients. We were not convinced and that is why a group of us visited Europe to study the law surrounding security institutions (The Lancet, 1982).

Professor Gunn told me that about 7,000 patients, namely $5 \%$ of a total of about 130,000 in-patients, were being detained in mental hospitals in the UK. When asked about the number of detainees in Japan, I had to confess I was ignorant of these figures. In order to answer his question, I tried to get the statistics.

Firstly, I was astonished that nobody, including the Ministry of Health and Welfare, had these important statistics about the number of mental hospital detainees. Secondly, I found that more than 240,000 patients, namely $80 \%$ of a total of 300,000 in-patients, were being detained in Japan's mental hospitals! This figure was five times bigger than the prison population. The patients were being detained indefinitely under Articles 29 and 33 of the Mental Hygiene Act.

In the UK, I also met Mr Larry Gostin, then Legal Director of MIND. He told me about the Mental Health Review Tribunal procedure, which guaranteed quasi-judicial hearings for detained patients in the UK; and the X v. UK case pending before the European Court. This eventually set a precedent concerning the right to independent reviews by the Tribunal for restricted patients. I was unaware of this important information. I then realised that no thorough comparative research had taken place in Japan either by scholars or lawyers into the law surrounding the detention of mental patients in Japan and in Europe.

I also began to realise that the Japanese Mental Hygiene Act provided none of the human rights guaranteed to detainees by the Japanese Constitution and the International Covenant on Civil and Political Rights. For those subject to detention proceedings, and those already detained, the Mental Hygiene Act provided no court procedure, no independent tribunal, no communication, no visiting, no lawyer, no advocate, no hearing, no access to any report or document, no free and independent expert witness and no notification of the reasons for detention.

On my return to Japan, I discovered information in newspaper articles, books and medical journals about numerous incidents and examples of the violation of human rights of mental hospital patients. These included arbitrary detention over long periods of time without proper treatment; suspicious deaths; the alleged abuse of psychosurgery techniques and other therapies such as ECT and drug therapy; torture and inhuman or degrading treatment; human experiments; forced labour; and appalling conditions and overcrowding in wards. The situation was particularly bad in many private mental hospitals, where owners tended to care more about their profits than their patients. It is important to note that over $80 \%$ of 1,500 mental hospitals were privately owned. But none of this information succeeded in persuading either the general public or the Government to take any step to reform the law in order to protect mental patients.

Why was it in Japan that mental patients did not deserve human rights?

One possible explanation was that the people in Japan did not regard mentally ill persons as proper human beings or equal fellow citizens. Moreover, hundreds of laws and regulations discriminated against the mentally ill. They were not allowed access 
to swimming pools, public baths, ferries, art museums, historical monuments, local assemblies and so on. They were barred from becoming a barber, beautician, cook, interpreter, guide, and many other jobs. They were not entitled to the same social welfare benefits as the physically disabled.

\section{So what should be done?}

It was clear to me that radical legal reform was necessary to protect the human rights of mental patients in accordance with international standards. What should be done in order to achieve this? It was necessary to persuade both the Government and Parliament. But before this, I had to get the consensus of professional associations. That was a difficult task.

The Japan Federation of Bar Associations had adopted a resolution on medical malpractice including psychiatric abuses in 1971. In it, the federation had called for improvements in the areas of medical ethics and administration, but it had not demanded actual amendments to the laws.

At that time, the lawyers involved in these recommendations were not aware of the facts on mass detention in Japan or of the position on standards for mental patients' human rights outside Japan. The Daini Tokyo Bar Association, to which some $10 \%$ of the Japanese lawyers belonged, realised the seriousness of the situation and, in May 1982, set up the Subcommittee on Mental Health and Human Rights inside its existing Human Rights Committee. I was fortunate enough to be elected chair of this subcommittee for several years. Six months later, following intensive research and seminars conducted by the subcommittee, the Human Rights Committee of the Daini Tokyo Bar Association submitted its provisional report to the Human Rights Convention of the Japan Federation of Bar Associations. Although the Daini Tokyo Bar called for legal reform of the Mental Hygiene Act in its proposal, the federation turned it down, because of strong objections by some influential members who were against any legal reform.

The Japanese Society of Neurology and Psychiatry was already aware of the existing problems and had been strongly critical of the serious psychiatric abuses. Its board had adopted a resolution requesting its members to respect the ethical obligations of psychiatrists in 1969 . Its general assembly called for freedom of communication and visits in 1974 and abolished the practice of psycho-surgery in 1975. The problem was that most of these resolutions were not adhered to by many of the society's members.

Surprisingly, most Japanese psychiatrists already knew about the situation regarding mass detention which I thought I had discovered! Our relationship was very similar to that between the South American
Indians and Christopher Colombus. Colombus claimed to have discovered America but the Indians justifiably claimed that they had known it for a long time!

Some conscientious psychiatrists cooperated with the Daini Tokyo Bar Association, but they did not all agree among themselves. Most of them supported our criticisms of the government but they asked us not to propose any legal reform based on these criticisms. They thought legal reform would further harm patients' rights, because, in their view, the ruling conservative government and parliament has always succeeded in worsening these delicate situations.

Japan had no non-governmental organisation which could work on behalf of mental patients' rights because none had enough finance to support full-time staff.

The National Federation of Families of the Mentally Ill in Japan (Zenkaren) was a good organisation with several highly competent staff. It had been campaigning for legal reform which would give mentally ill people substantial social welfare benefits. They could not easily fight for human rights, openly criticising the abuse of patients in mental hospitals, because they felt their own family members were being detained as 'hostages'. Another problem was that family members were obliged to give consent to detention of mentally ill relatives under Article 33 of the Mental Hygiene Act and this had led to conflicting interests between patients and families exacerbated by the existing laws.

The Liberal Democratic Party, the long-running ruling party, had formed the 'Forum on Social Rehabilitation for Mentally Ill Persons' which had been cooperating with the families of mental patients. But private mental hospitals, which were wealthy, had good contacts with the party. As a result, it was extremely difficult for us to persuade the party to accept demands for radical legal reforms on the human rights of mental patients.

When I began my work as a full-time volunteer independent advocate for a legal reform, I realised that I and my few supporters could never achieve the changes that were needed inside Japan. The situation looked hopeless. I knew that three books on the subject were about to be published by us, but there would be no hope of a change in the law in the near future. I decided to go to the United Nations to raise the issue in order to stimulate Japan and raise awareness in the international community. There seemed to be no other alternative.

\section{Seeking international help}

I learnt that, in order to raise these issues in the international community such as at the United 
Nations, international non-governmental organisations (NGOs) in consultative status with the UN played a vital role. They had the legal status to speak and submit their statements in various UN procedures and they could join in discussions to formulate international standards of law and implement these standards. Furthermore, international NGOs which enjoyed a high reputation such as the International Commission of Jurists (ICJ), Amnesty International and so on, could create a big impact on member countries' governments by publishing articles, sending fact-finding missions to a particular country, publishing their reports and making interventions at various UN meetings. I was very fortunate in being able to establish contact with several influential international NGOs which were seriously concerned about mental health and human rights.

The reform which later took place in Japan would not have been possible without the willingness of those NGOs to help Japanese mental patients. These included the International League for Human Rights, Disabled Peoples' International, the International Commission of Jurists, the International Commission of Health Professionals and the World Federation for Mental Health.

After our bar had been engaged in an intensive campaign for more than one and a half years, some disturbing and new confidential information on the serious abuse of mental patients in Japan started reaching us. Needless to say, allegations brought by ex-mental patients were difficult to prove, because mental hospitals were isolated and a completely closed world. One of the most disturbing cases was verified by a team of journalists from the Asahi Shimbun newspaper with cooperation from the staff of the Japan Socialist Party and some lawyers including ourselves. It has been a cause celèbre since 14 March 1983 when the Asahi Shimbun and two other major newspapers reported that two detained patients had been beaten to death by staff of the privately owned Hotokukai Utsunomiya Hospital. The most striking revelation at Utsunomiya Hospital was the number of deaths, 222 within three years among some 1,000 in-patients. Although the circumstances surrounding these deaths were extremely suspicious, only eight cases among 222 had been examined by the authorities concerned before the scandal was revealed. There was no way for the authorities to conduct thorough investigations of these 222 cases, as the bodies had already been cremated and inquests had not been held because Japanese law was defective in this area. It was found that many patients were being detained illegally even under the inadequate Mental Hygiene Act. Violence was rife and there was no proper supervision by the authorities nor any way of protecting patients. While this was going on, the family that owned the hospital was continuing to accumulate wealth.
This information was added to the previous information which had been handed to the ICJ. Subsequently Mr Niall MacDermot, Secretary General of the ICJ, sent a letter to the then Prime Minister Mr Yasuhiro Nakasone in May 1984, "suggesting to consider appointing an independent commission to enquire into the treatment of mental patients and the legislation relating to it". The Prime Minister's Office did not reply and later said they had not been able to find the letter.

In June 1984, the ICJ published an article entitled 'The Mentally Ill in Japan' in its periodic review. This succeeded in disseminating information about the Japanese problem to the world.

The Japanese Constitution (1946) promised that Japan will faithfully observe established international laws. And Japan had always held the UN in great respect.

In August 1984, having been requested by the Japan Civil Liberties Union, of which I am a member, the International League for Human Rights (ILHR) took the issue to the UN Sub-Commission on Prevention of Discrimination and Protection of Minorities. The ILHR submitted a written statement under the agenda item 'Human rights and scientific and technological development' and also made an oral intervention during the open session of the SubCommission. This allegation of grave human rights abuse of the mentally ill in Japan was widely reported by major national newspapers and international media such as the International Herald Tribune. Another NGO, Disabled Peoples' International, also joined in the debate and severely criticised the Japanese Government on the same issue.

The Japanese Government responded and substantially denied those allegations before the SubCommission, saying that serious abuses constituted no more than a few exceptional isolated cases; that the compulsory hospitalisation figures were $12 \%$ not the $80 \%$ we claimed. This discrepancy is explained by the fact that the Government did not include involuntary admission with family consent in their figures. The Government also claimed that legal procedures for detention were not violating international laws, and that administrative measures to supervise mental hospitals were satisfactory. The only point we found encouraging was that the Government promised it would carefully study and follow international trends.

After the Government denied the allegations, the ILHR sent a letter to the Prime Minister, which raised other examples of mental hospital scandals reported even after the Utsunomiya scandal. The letter also objected to the Government's exclusion from their figures on involuntary committal of the patients who had been committed to mental hospitals by hospital administrators and family consent but without patient consent (under Article 33 of the 
Mental Hygiene Act). This triggered a debate in Parliament where the Government could not give a satisfactory explanation. But it still refused to admit any need for legal reform.

International NGOs often send fact-finding missions to countries where gross violations of human rights are reported. The reports of such missions are submitted to the UN organs and create great impact on human rights standards in that particular country.

Japan had not in the past been subjected to this type of rigorous scrutiny. It was the ICJ/ICHP mission which persuaded Japan to take a step forward in the reform of its mental health legislation. The ICJ decided to send a mission to Japan in response to our request in September 1984, as the Prime Minister had not responded to the letter from the ICJ. The mission was co-sponsored by the newly-formed International Commission of Health Professionals. The Japanese Committee of the Fund for Mental Health and Human Rights was formed in order to receive the mission. It comprised 18 prominent multi-disciplinary figures in the fields of law and mental health.

The four members of the ICJ/ICHP mission visited Japan for two weeks in May 1985. Although the officials from the Ministry of Health and Welfare were apprehensive when they first received the mission, after frank exchanges the atmosphere lightened. The Private Mental Hospitals Associations did not hide their hostility towards the mission. However, some kind of mutual understanding was established after more friendly discussion. It seemed to me that, through this encounter, these two main policy makers of Japan's mental health system realised, to a certain extent, that it might not be possible to hold on to the old mental health policies and attitudes towards mental patients' rights. The Conclusions and Recommendations of this independent experts' mission were made public in July 1985, but they were made available to the Government of Japan much earlier (Harding et al, 1986). The mission supported our bar's view in these findings. The Government reserved the right to comment against the forthcoming final full report. It seemed that at last serious discussion on reform of the Mental Hygiene Act was underway.

Another debate on the human rights situation of Japanese mental patients took place in August 1985 before the UN Sub-Commission on Prevention of Discrimination and Protection of Minorities. The ICJ, the ILHR and the DPI criticised Japan.

The ICJ referred to its mission's findings and suggested:

(a) urgent legal reform of the Mental Hygiene Act in order to protect human rights of mental patients (b) improvement and re-orientation of mental health services; namely, total revision of the mental health system encouraging voluntary hospitalisation, rehabilitation and community care

(c) improved education and training in the mental health field.

Responding to these NGOs' statements, the Government of Japan, for the first time in Japanese history, officially declared before the United Nations that Japan had decided to take the necessary steps to amend the Mental Hygiene Act for the further protection of human rights of mental patients (Totsuka, 1985). This was a turning point in the history of mental health and human rights in Japan.

I believe that this important step forward will improve the standard of human rights for mental patients. But more importantly this change of heart will lead to valuable advances in the whole attitude towards the care of the mentally ill - in areas where the law cannot always enter.

Eventually, in March 1987, the Cabinet submitted the bill proposing the new Mental Health Act to Parliament after complicated procedures which involved the approval of the ruling Liberal Democratic Party. The LDP admitted that the changes were necessary because of international criticism.

Regrettably, the main obstacle to the reform of the mental health system was the Private Mental Hospitals Association. Resistance from the association constituted a serious threat to the bill as it had powerful contacts both in the Government and in the Opposition. Some very influential MPs in the Government and Opposition who were persuaded by the Private Mental Hospitals Association tried to block the new Mental Health Act and almost succeeded in the summer of 1987. This attempt to sink the bill was severely criticised by the ICHP, the WFMH and DPI in the UN Sub-Commission on Prevention of Discrimination and Protection of Minorities in August 1987. With international support for the reform, the ruling Liberal Democratic Party maintained its position urging that the bill be made law as it stood. In the end, Parliament rejected the main demands of the Association and the bill became law on 18 September 1987 with only relatively minor changes. The Act came into force on 31 July 1988.

\section{New Mental Health Act}

Now let us look at what has actually been achieved by the recent legal reform.

A provision was included stating that superintendents of mental hospitals must make efforts to admit the mentally ill with their consent where hospitalisation is necessary. This could be seen as the greatest achievement in the recent legal reform, as previously 
Japanese law had no concept of a voluntary hospitalisation. This clearly demonstrated Japan's philosophy which has always considered that all mentally ill people are incompetent. Mindful of the fact that British law first introduced the concept of voluntary hospitalisation in 1930, it has taken Japan a very long time to catch up.

The new law empowered the Minister of Health and Welfare to set forth regulations on standards for the treatment of mental hospital patients. Restrictions on actions such as the sending and receiving of correspondence by in-patients, meetings between government employees and the in-patients, and certain other actions designated by the Minister, are now prohibited by the new law. These are indeed a big step forward as, under the previous law, doctors were able to play God and had discretionary powers to restrict all patients' freedoms, as a matter of course, and were able to exercise any kind of compulsory medical treatment. As a result, not even a government minister could intervene in the medical practice that prohibited patients from seeing a lawyer, because this and other restrictions were considered to fall within the area of medical discretionary powers-or clinical judgement. It is abundantly clear now, however, that the new law compels Japan to abandon the old philosophy of unrestricted professional freedom of psychiatry.

Patients who are involuntarily admitted to a mental hospital are able to request the Prefectural Governor to order the necessary measures for improvement of treatment or discharge under the new Psychiatric Review Boards (PRB) which are set up by the new law in each prefecture to handle the above requests and advise the Governor who may order improvement of treatment or discharge. Hospital superintendents must inform patients of their right to these requests in writing. Patients had none of the above rights under the previous law. The introduction of the right to complain demonstrates that Japan has admitted that mentally ill people are human beings who may enjoy the same human rights as the ordinary citizen.

For the first time, the new law made it possible for prefectural governments, other local governments, social welfare corporations and others to be authorised to establish social rehabilitation facilities, and sheltered workshops for the mentally ill. And national and prefectural government may subsidise the building and running costs of these rehabilitation facilities. This also represents an important change in the philosophy in the Mental Health Act, as the previous law had no such provision for social rehabilitation.

Although only a small number of our own proposals for reform were incorporated, these changes in the philosophy in the Mental Health Act could well trigger an overall reform. This depends upon whether the changes in the law affect the philosophy of those who are working in the field of mental health and human rights, of the administration of national and local government, of Parliament, and above all of the general public.

The new law will be subject to an official review in five years to see whether further changes will be needed. This is incorporated in an article of the new law and will provide an opportunity for many issues to be raised which could not be agreed upon in time for the 1987 legislation. We Japanese lawyers have made strong criticisms of the new law, as it has some serious defects. The debate will have to continue.

\section{Is further reform possible?}

Legal reform constitutes only one part of the ICJ/ ICHP recommendations. The 'Improvement and Re-orientation of Mental Health Services' and 'Improved Education and Training in the Mental Health Field' were strongly recommended to Japan's Government. Law in itself is not omnipotent. There are a great many tasks which need to be tackled that are outside the confines of the law. We have many difficulties. These include lack of vision and leadership in these areas; lack of willingness to participate in international activities; lack of openness with information and research; lack of a constructive approach; lack of finance, of a training system for professionals and of an effective consumer organisation.

Despite all this, the change in attitude of the people in Japan towards mental patients triggered by the debates on mental patient's rights has been important. One example of this is the efforts of health professionals to try to create training systems for themselves which they did not have before. The Japanese Society of Neurology and Psychiatry recently set up a Committee for Training. Clinical psychologists and psychiatric social workers have also begun to create their own training programmes. These are areas where the law cannot play a significant role. For example, the lawyers cannot train good psychiatrists or treat patients.

Needless to say, the role of the government is the most important. I really appreciate the recent enormous change in attitude of the Japanese Ministry of Health and Welfare. The Ministry was receptive to some of the recommendations made by the international non-governmental organisations. I am sure that the government can and will go on further in its efforts to improve the situation.

But it will be difficult for it to do so without constructive help and advice from voluntary organisations. I believe that in order to cope with the discrimination against and the neglect of the mentally ill, Japan needs to have a strong, well-financed and 
well-staffed consumer oriented organisation like MIND in the UK and further support from existing voluntary organisations.

Finally, Japan needs to have more international support on these issues. Without this, true reform will never be achieved.

\section{Acknowledgements}

I would like to thank Ms Joan Shenton for her linguistic advice which was extremely helpful.

I also greatly appreciate the kind understanding of $\mathrm{Mr}$ Niall MacDermot, Secretary General of the ICJ; Dr N. W. de Smit, Chairman of International Seminar on Mental Health Legislation; and Dr Robert Myers, then President of the ANZAPPL for their kind understanding in my using many parts of my previous lectures: Development in Mental Health Legislation in Japan, which was published by the Faculty of Law of Vrije Universiteit in the Proceedings of International Seminar on Mental Health Legislation, Amsterdam (October 1988) and The Changing Face of Mental Health Legislation in Japan, which was the keynote address for the 9th annual Congress of the Australian and New Zealand Association of Psychiatry, Psychology and a joint Congress of the American Academy of Psychiatry and the Law, Melbourne, Australia (October 1988) and published by the International Commission of Jurists in the Review No. 42 (June 1989).

\section{References}

FukazaWA, S. (1964) Narayamabushi-ko. Tokyo: Shincho-sha.

Harding, T., Schneider, J., Visotsky, H. \& Graves, C. (1986) Human Rights and Mental Patients in Japan. Geneva: International Commission of Jurists, pp. 5-6.

The InTERnational Commision of JuRISTS (1984) The mentally ill in Japan. The ICJ Review, 32, 15-20.

KANEKO, J. (1973) Nihon igaku-shi nenpyou. Tokyo: NihonSeishinbyouin-Kyoukai, pp. 156,332,336-341.

THE LANCET (1982) Japan: Human rights of mentally ill offenders. The Lancet, i, 673.

TotsUKA, E. (1985) Ningensei kaihuku eno michi. In Seishin-iryo to jinken (3) Ningensei kaihuku eno michi (eds. E. Totsuka and I. Hirota). Tokyo: Aki-shobo, pp. 199-240.

\title{
The use of adult psychiatric day care facilities in Worcester
}

\author{
Margaret du Feu, Senior Registrar in Psychiatry, All Saints Hospital, \\ Birmingham B18 5SD
}

The 1975 White Paper Better Services for the Mentally IIl recognises different roles for day hospitals, day centres and the voluntary sector in the provision of psychiatric day care. Two broad client groups, needing short-term support or long-term care, are described. However, Vaughn (1983 and 1985) and Wilkinson (1984) have reviewed lack of co-ordinated planning in the provision of services and the place- ment of clients. Carter (1981) in a major survey of day care, showed that in many cases it was difficult to differentiate between day hospital and day centre services or client groups.

Worcester provides a unique opportunity for the study of day care use. The Worcester Development Project was set up as a local pattern of psychiatric services with funding from the DHSS in order to test 